\title{
The Competency of Elementary School Teachers in Solving TIMSS Mathematics Problems
}

\author{
Dimas Muharam, Sri Wuryanti*, Rumondang Purwati, Fahmi \\ Pusat Asesmen dan Pembelajaran \\ Kementerian Pendidikan dan Kebudayaan \\ Jakarta Pusat, Indonesia \\ Dimas.muharam@kemdikbud.go.id, sriwuryanti03@gmail.com*, rumondang@gmail.com,ffahmi6@gmail.com
}

\begin{abstract}
This study aims to obtain information about elementary teacher competencies in solving math problems. This research uses quantitative and descriptive methods. Quantitative methods are used to determine elementary school teacher competency, proportion correct, and item difficulty, while descriptive methods are used to inform test scores, proportion correct, and item difficulty in tabular and graphic form so that they are easy to read and understand. The population of this study is all the reference elementary schools in Indonesia, while the sample is determined by simple random sampling. The number of sample schools was 101 schools, while the objects of this study were 101 elementary school teachers. Analyzes were performed using Excel to determine test scores, item difficulty, and proportion correct. From the results of the analysis, it can be concluded that as many as $44 \%$ of teachers scored above 80 , but as many as $11 \%$ of teachers scored less than $\mathbf{5 0}$. The proportion is correct of probability above $80 \%$ higher than the proportion correct of geometry and measurements and numbers. The highest proportion correct of cognitive domain knowing is $\mathbf{8 3 . 8 9 \%}$ and the lowest proportion correct of cognitive domain reasoning is $41.73 \%$. The proportion correct of the material tested for fractions and decimals, geometric shapes, and organization and presentation of data is above $80 \%$, while the proportion correct of other materials is below $80 \%$. The proportion correct of elementary school mathematics material is quite good in the category of $\mathbf{7 5 . 8 8 \%}$, but the number or measure of diversity is quite high with a standard deviation of $167 \%$. This is also seen from the lowest proportion correct of $23.22 \%$ and the highest $\mathbf{9 6 . 8 3 \%}$. That is, there is a fairly high variation or gap between teachers with the lowest and highest mastery of the material, even though the tendency for achieving teacher scores is quite good. The level of mastery of teachers answered correctly the multiple-choice items $\mathbf{7 6 . 7 7 \%}$ and the essay items $\mathbf{7 5 . 2 7 \%}$.
\end{abstract}

Keywords - teacher elementary school, mathematic, assessment, TIMSS

\section{INTRODUCTION}

Improving the quality of Human Resources (HR) is a demand that cannot be ignored and is a concern of various institutions and countries in various parts of the world, including Indonesia. Good quality human resources can only be obtained through a planned and systematic effort through qualified education.

Education must be designed as well as possible so that the teaching and learning process in the classroom runs optimally. Learning in the classroom should leave conventional learning methods that merely pursue scores and ignore competence. One indicator of the quality of education is the success of students in mastering the subject matter and this depends on how much the teacher as an educator has mastered the subject matter he is teaching. According to Hamalik [1] and Sudjana [2], learning outcomes are the abilities of students obtained after learning. Learning outcomes can be seen from changes in behavior for the better than before. Changes in behavior towards learning outcomes are continuous, positive, active, and directed.

Several research results on the quality of education in Indonesia still show unsatisfactory results. Although there was an increase in the results of the 2015 PISA study, this increase was not significant. In the study, mathematics competence increased from 375 points in 2012 to 386 points in 2015. According to the results of the 2015 TIMSS study for grade 4 elementary school students, Indonesia is in 45 th out of 50 countries for mathematics and 45th out of 48 countries for science. From the results of the PIRLS [3], TIMSS [4], and PISA [5] studies it can be concluded that Indonesian students are still weak in solving questions that require reasoning. In line with the results of this study, research conducted by Hartatiana [6] states that only $6 \%$ of students can solve math problems using the PISA model. Related to this, a study is needed to determine the competence of elementary school teachers so that input is obtained to improve the quality of education. The purpose of this study was to determine the competence of elementary school mathematics teachers, the mastery level of subject matter, and the difficulty level of the items.

\section{LITERATURE}

Education in essence cannot be separated from human life. Education is one way to instill values through the learning process and is a measure of the progress of a nation. Superior 
human resources are the initial capital for a nation to be able to play a role and compete in any part of the world. Superior humans can be produced through qualified education. Quality is related to the assessment of a product in meeting certain criteria, standards, or references. According to Suderadjat [7], qualified education must be able to produce graduates who have competencies, both academic and vocational competencies, which are based on personal and social competencies, as well as noble moral values, which are all life skills. According to Godwin [8], one of the factors causing the low quality of education in Indonesia is the lack of creativity of educators in presenting subject matter. Educators who are less capable of teaching and who do not master the material being taught can cause dislike for what is being taught and a lack of encouragement to master it on the part of students. On the other hand, educators who are good at teaching can give students a feeling of liking the material they are teaching so that without prompting students can increase their knowledge a lot.

The very fast development of science in the 21 st century, especially in the field of information and communication, which is all sophisticated, has made this world even narrower. Various information can be accessed quickly, easily, cheaply by anyone and from anywhere. These changes are increasingly felt in the world of education. Education reform must be carried out to face the fast-paced development of science, especially improvements to curricula, textbooks, and increase the competence of educators. Educators in this century face challenges that are far more diverse than teachers in the previous era, more complex subject matter, and demands for higher thinking or reasoning abilities of students. Educators who can face these challenges are professional educators who have good pedagogical competence, personality competence, social competence, and academic competence. Education in the 21 st century requires students to have and be able to think critically and solve problems, think creatively and innovatively, and collaborate and communicate effectively [9]. These essential skills are higher-order thinking skills that are needed by students as useful members of society in life. One of the measuring tools used to determine the mastery of subject matter by students is in the form of learning outcome tests. The test results are expected to provide accurate and reliable information. The test is a standard process for obtaining a sample of behavior from a certain domain [10]. Anastasi and Urbina [11] say that achievement tests measure a person's knowledge due to an educational program or a training program. According to Umar [12], a test is a set of questions that must be answered, or statements that must be responded to, or tasks that must be performed by the person being tested to measure a certain behavior aspect of the person being tested. So it can be said that to make a test must go through a standard process so that the test results can be trusted. In line with this, Azwar says that achievement tests must be arranged in a planned manner to reveal the extent to which students can master the subject matter that has been taught by the objectives [13]. One of the steps in developing the test is analyzing the item questions qualitatively and quantitatively. Qualitative analysis is carried out to determine whether the items that have been written are by the rules of writing the questions, while quantitative analysis of the items is carried out to determine the item difficulty, the item discrimination, and the reliability of the test. According to the Ministry of Education and Culture [14], the form of questions on the written test consists of objective forms (multiple-choice, true-false, matchmaking, filling or completing, short answers), while non-objective questions include essay questions. Each form of question has advantages and limitations. One of the limitations of essay questions is that the scoring is less consistent and subjective. According to Nitko [15], a rubric is a tool in which there is a set of criteria used to score student performance. To make a good test is not easy. The results of research conducted by Kartowagiran and Jaidun [16] and Setiadi [17] show that educators still do not understand the assessment process and still need guidance in conducting assessments. The thinking process is grouped into 3 cognitive levels, namely [18]: level 1 knowledge and understanding, level 2 application, and level 3 reasoning. 3 things must be considered in making essay questions, namely: 1) using a stimulus; 2) using a new context, and 3) distinguish between the difficulty level and the complexity of the thinking process.

The implications of the effect of the competence of mathematics teachers on creative teaching according to the domain of knowledge, skills, and attitudes, and personality are [19]: The competence of math teachers should be given due attention to creative teaching practices. The three domains of teacher competence namely knowledge, skills and attitudes, and personality need to be aligned and mastered in determining the competence of a mathematical teacher. Pupils will have a direct impact if mathematics teachers are not or less competent in teaching. Country aspirations to create creative and innovative human capital and to compete in the rankings. Global is difficult to realize if teachers do not have the necessary competencies. Regression results show that mathematical competencies are very influential in improving prospective teachers' pedagogical competencies in Primary School [20]. The importance of mathematical competencies for prospective teachers must be used as a benchmark for obtaining high pedagogical competencies for prospective teachers. According to Nambira [21] to teachers, the conceptualization of mathematics knowledge and pedagogical principles are crucial in managing the curriculum and assessment principles. Henceforth, teachers with low qualifications will have trouble in developing lesson plans and preparation. The conclusion is that Math teacher competencies in creative teaching according to the domain of knowledge, skills, and attitudes, and personality are: Math teacher competencies must be given because they pay attention to creative teaching practices. Three domains of teacher competence, namely need to be aligned and mastered in determining the competency of mathematics teachers. Students will have a direct impact if the mathematics teacher is not or less competent teaching the teacher in elementary school. The importance of mathematical competence for prospective teachers must be used as a benchmark to get high pedagogical competencies for prospective teachers. conceptualization of mathematical 
knowledge and pedagogical principles is very important in managing curriculum and assessment principles. Furthermore, teachers with low qualifications will have difficulty in developing lesson plans and preparation.

Arnold [22] goes on to give evidence that visual imagery may in some cases play an important role in elementary math's processes. Tentatively, Hayes suggests that "all our results are consistent in indicating an important function for notationrelated imagery in the solution of elementary mathematical problems. Perhaps it provides another route to mathematical understanding, which does not rest entirely on linguistic skills.

According to Chen [23], math origami can be used as an entry point to mathematical discourse and applications called for by the U.S. National Council of Teachers of Mathematics and other reform efforts. Implemented as a math-based activity, origami makes mathematics more visual and hands-on. Conclusion Mathematics is learning which is done by providing visual evidence in some cases can play an important role in the basic mathematical process. All of our results are consistent in showing important functions for dealing with notations in solving basic mathematical problems. Perhaps this provides another route to mathematical understanding, which does not depend entirely on linguistic skills. Mathematics can be used as an entry point for discourse on reform efforts. Implemented as a practice-based mathematical activity, origami makes mathematics more visual, and with hand skills is visual and practice.

\section{METHODS}

The population of this study was all reference primary schools throughout Indonesia, while the sample was determined by simple random sampling. Random sampling was carried out on reference primary schools in all provinces in Indonesia. The number of sample schools was 101 schools, while the object of this study was 101 elementary school teachers. The analysis was performed using Excel to determine the test score, the items difficulty level, and mastery of the subject matter described by proportion correct.

\section{RESUlTS AND DisCUSSION}

The shows the results the distribution of the of 101 elementary school teachers is presented in Figure 1.

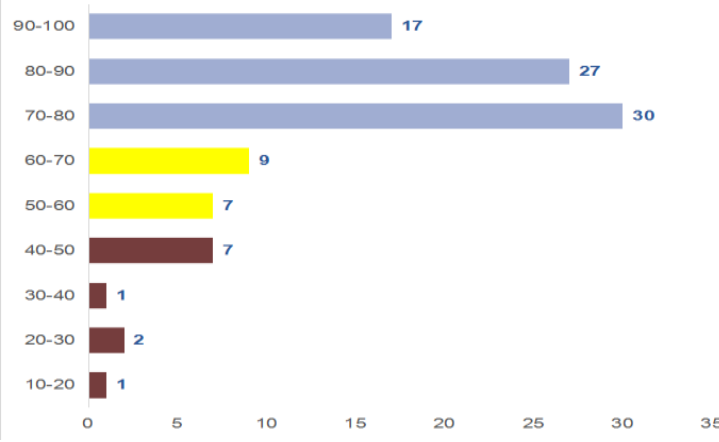

Fig. 1. Distribution of primary school teacher mathematics test scores.
From Figure 1 above, as many as $44 \%$ of Mathematics teachers scored above 80 as $11 \%$ of teachers scored less than 50. Distribution of content domains, cognitive domains, and proportion correct is presented in Table 1 and Table 2.

TABLE I. PROPORTION CORRECT OF CONTENT DOMAIN AND COGNITIVE DOMAIN IN MATH TEST

\begin{tabular}{|l|c|}
\hline \multicolumn{1}{|c|}{ Content Domain } & Proportion Correct (\%) \\
\hline Number & 74,91 \\
\hline Geometry and Measurement & 75,45 \\
\hline Data and Probability & 81,66 \\
\hline Cognitive Domain & 83,89 \\
\hline Knowing & 77,93 \\
\hline Applying & 41,73 \\
\hline Reasoning & \\
\hline
\end{tabular}

TABLE II. PROPORTION CORRECT OF CONTENT TESTED IN MATH Test

\begin{tabular}{|l|l|l|}
\hline \multicolumn{1}{|c|}{$\begin{array}{c}\text { Domain } \\
\text { Content }\end{array}$} & \multicolumn{1}{|c|}{ Content } & $\begin{array}{c}\text { Proportion } \\
\text { Correct (\%) }\end{array}$ \\
\hline \multirow{2}{*}{ Number } & Whole number & 73.36 \\
\cline { 2 - 3 } & Fractions and decimals & 86.15 \\
\hline \multirow{2}{*}{$\begin{array}{l}\text { Geometry } \\
\text { and }\end{array}$} & Geometry shapes & 81.25 \\
\cline { 2 - 3 } Measurement & Measurement & 23,22 \\
\cline { 2 - 3 } $\begin{array}{l}\text { Data and } \\
\text { Probability }\end{array}$ & Location and displacement & 79.32 \\
\cline { 2 - 3 } & Organization and presentation of data & 81.43 \\
\hline
\end{tabular}

In Table 1 and Table 2 above, the proportion correct of the content domain for data and probability is above $80 \%$, this is higher than the proportion correct of the content domain for geometry and measurement and numbers. The highest proportion correct of the cognitive domain was $83.89 \%$ at the cognitive domain of knowledge and the lowest was in the cognitive domain of reasoning, which was $41.73 \%$. This shows that the competence of teachers in solving reasoning questions is still inadequate. The proportion correct of the content tested for fractions and decimals, geometric shapes, as well as the organization and presentation of data is above $80 \%$, while proportion correct of other contents is below $80 \%$. In this case, the proportion correctly describes mastery of mathematics subject matter.

Mastery of mathematics subject matter in elementary school teachers with a fairly good category was $75.88 \%$, but the diversity was quite high with a standard deviation of 1,67. That is, there is a fairly high variation between the teacher with the lowest and the highest mastery of mathematics subject matter, although the tendency to achieve scores is quite good. Mastery of subject matter in various forms of questions is presented in table 3 below.

TABLE III. PROPORTION CORRECT BASED ON FORMS OF QUESTIONS

\begin{tabular}{|l|c|}
\hline \multicolumn{1}{|c|}{ Form of Questions } & Proportion Correct (\%) \\
\hline Multiple Choice (MC) & 76,77 \\
\hline Essay/Completing & 75,27 \\
\hline
\end{tabular}


From table 3, there the mastery level of teachers who work on multiple choice questions (average mastery of subject matter is $76.77 \%$ ) and those who work on questions in the form of essay (average mastery of subject matter is $75.27 \%$ ). The following is an example of the questions and the proportion correct of the items based on the cognitive domain.

A. Example 1

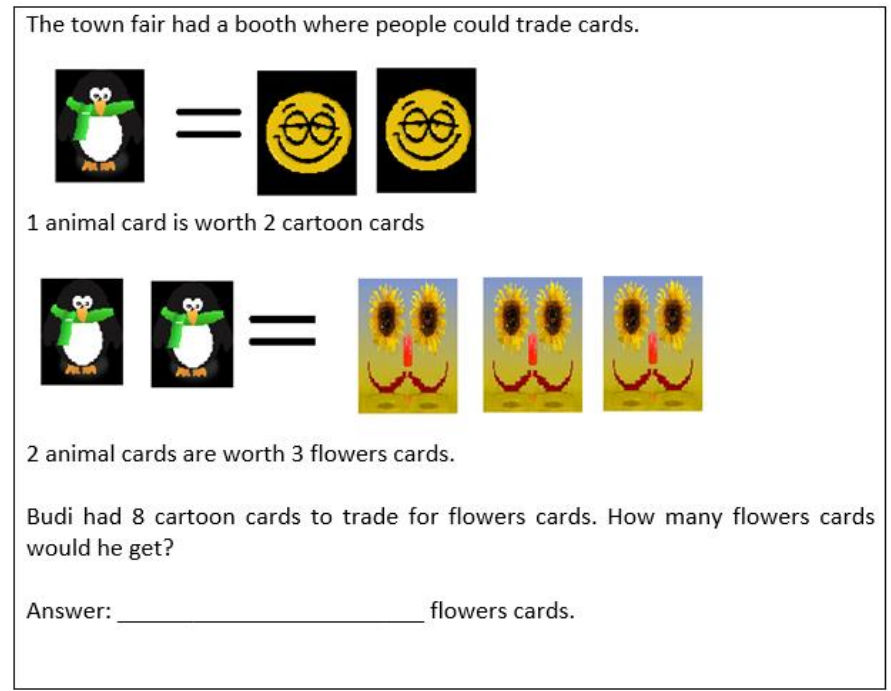

Fig. 2. Example 1.

This question measures the competence of simple math equations with variables (Figure 2). This question includes the cognitive level of reasoning with the content domain was numbers. This question can be answered correctly by $37.18 \%$ of teachers. However, what needs to be worried is that this question is given to teachers.

\section{B. Example 2}

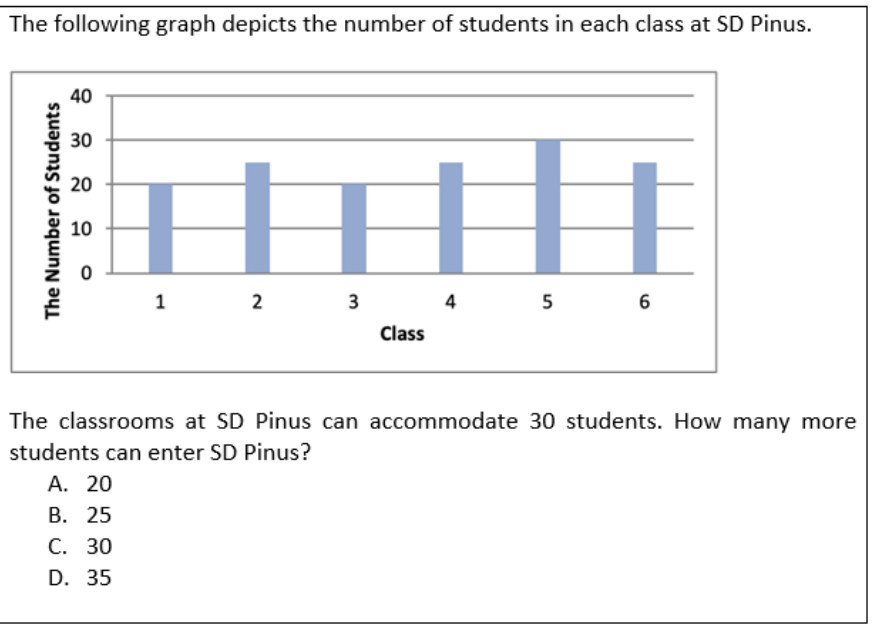

Fig. 3. Example 2.
This measures the competence of reading the data presented in a bar graph (Figure 3). This question includes the cognitive level of application with the content domain of data and probability. This question is in the easy category, $76.42 \%$ of teachers can answer correctly, however, there are still $23.58 \%$ of teachers who answered incorrectly.

\section{Example 3}

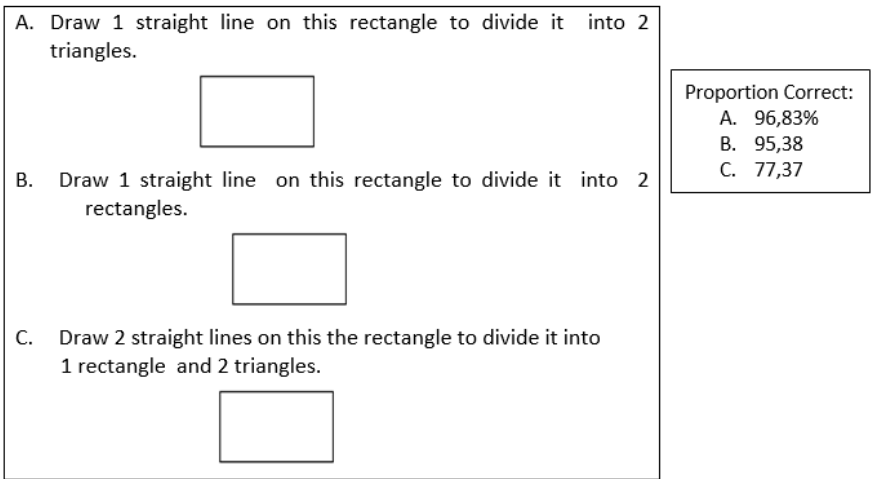

Fig. 4. Example 3

This question (Figure 4) measures the competence of dividing a rectangle with a straight line into two triangles (A), two rectangles (B), one rectangle, and two triangles. This question includes the cognitive level of knowledge with the geometric and measurement content domains. This question belongs to the easy category with the lowest proportion correct of $77.37 \%$.

\section{CONCLUSION}

Some variations or gaps are quite high between teachers with the lowest and highest mastery of subject matter, even though the tendency to achieve teacher scores is quite good. The proportion of correct answers to multiple-choice questions and essays is not much different.

\section{REFERENCES}

[1] O. Hamalik, Proses Belajar Mengajar. Jakarta: PT Bumi Aksara, 2006.

[2] N. Sudjana, Penilaian Hasil Proses Belajar Mengajar (Cet. XV). Bandung: PT. Ramaja Rosdakarya, 2010.

[3] PIRLS, International Report, Performance at the PIRLS 2011 International Benchmarks TIMMS \& PIRLS Report International Study Center (IEA): Lynch School of Education, Boston College, 2011

[4] IEA's Trends in Internasional Mathematics and Science Study, "Math Student Achivement Infographic Grade 4, TIMSS 2015.” 2016. [Online] Retrieved from: http://timss2015.org/download-center

[5] Kementerian Pendidikan dan Kebudayaan, "Peringkat dan Capaian PISA Indonesia Mengalami Peningkatan,” 2016. [Online] Retrieved from: https://www.kemdikbud.go.id/main/blog/2016/12/peringkat-dancapaian-pisa-indonesia-mengalami-peningkatan

[6] H. Hartatiana, "Kemampuan Berpikir Tingkat Tinggi Siswa SMP dalam Menyelesaikan Soal Matematika Model PISA." Jurnal Pendidikan Matematika, vol. 14, pp. 15-24, 2020. 
[7] H. Suderadjat, Manajement Peningkatan Mutu Berbasis Sekolah. Bandung: CV. Cipta Cekas Grafika, 2005.

[8] R. Godwin, "Rendahnya Kualitas Pendidikan di Indonesia," 2017. [Online] Retrieved from: https://psychology.binus.ac.id/2017/02/17/rendahnya-kualitaspendidikan-di- indonesia/

[9] Pusat Asesmen dan Pembelajaran, Pengembangan Soal AkademikAKM. Pusat Asesmen dan Pembelajaran, 2020.

[10] L. Crocker and J. Algina, Introduction to classical and modern test theory. Orlando, FL: Holt, Rinehart and Winston, 1986

[11] A. Anastasi and S. Urbina, Psychological Testing. New York: Macmillan Publishing Company, 1988.

[12] J. Umar, Bahan Penataran Pengujian Pendidikan. Jakarta: Departemen Pendidikan dan Kebudayaan, 1998.

[13] S. Azwar, Tes Prestasi Fungsi dan Pengembangan Pengukuran Pretasi Belajar. Yogagyakarta: Pustaka Pelajar, 2000.

[14] Kementerian Pendidikan dan Kebudayaan, Pedoman Penilain Kelas Berdasarkan Kurikulum 2013, Kementerian Pendidikan dan Kebudayaan, 2014.

[15] A.J. Nitko, Educational Assessment of Students, Engliwood Cliffs, Prentise-Hall, Inc., 1996.

[16] B. Kartowagiran and A. Jaidun, "Model Asesmen Autentik untuk Menilai Hasil Belajar Siswa Sekolah Menengah Pertama (SMP):
Implementasi Asesmen Autentik di SMP," Jurnal Penelitian dan Evaluasi Pendidikan, vol. 20, no. 2, 2016.

[17] H. Setiadi, "Pelaksanaan Penilaian pada Kurikulum 2013," Jurnal Penelitian dan Evaluasi Pendidikan, vol. 20, no 2, 2016.

[18] Pusat Penilaian Pendidikan, Panduan Penulisan Soal HOTS-Higher Order Thinking Skills. Pusat Penilaian Pendidikan, 2019.

[19] A. Jusoh, M. Salleh, R. Embong, and M. Mamat, "The Influence of Mathematical Teacher Competency on Creative Teaching Practice,' International Journal of Academic Research in Progressive Education and Development, vol. 7, pp. 397-409, 2018

[20] D.A. Kurniawan, F. Chan, P. Nugroho, R.A. Pratama, and R. Septiasari, "Identification: The effect of mathematical competence on pedagogic competency of prospective teacher," Humanities \& Social Sciences Reviews, vol. 7, pp. 85-92, 2019.

[21] G. Nambira, "Analyzing the determinants of teachers' mathematics teaching competencies in upper primary phase: evidence from Namibia,' International Journal of Innovation and Economic Development, vol. 2, pp. 35-47, 2016.

[22] P. Arnold, "Deaf children and mathematics," Hrvatska revija za rehabilitacijska istraživanja, vol. 32, pp. 65-72, 1996

[23] K. Chen, "Math in motion: Origami math for students who are deaf and hard of hearing," Journal of deaf studies and deaf education, vol. 11, pp. 262-266, 2006. 